УДК 343.31

\title{
RUSSIA'S HYBRID WARFARE AGAINST UKRAINE IN THE CONTEXT OF EUROPEAN SECURITY
}

\author{
Natalya Antonyuk, Markiyan Malskyy \\ Ivan Franko National University of Lviv, \\ 1, Universytetska Str., Lviv, Ukraine, 79000, tel. (+38032) 239-46-56, \\ e-mail:nantonyk@yahoo.com; malskyy@ispc.org.ua
}

The peculiarities of the Russian-Ukrainian conflict («hybrid warfare») have been analyzed in the paper, as well as its importance to the European security has been revealed. The causes of the RussianUkrainian conflict have been highlighted in particular. The term «hybrid warfare», its signs, methods and structural elements have been characterized. The application of the «hybrid warfare» term has been justified for the Ukrainian realities. Special attention has been paid to the information component of hybrid warfare in Ukraine. The basic methods of Russia's information aggression against Ukraine have been provided, including misinformation; propaganda; diversification of public opinion; psychological and psychotropic pressure; rumormongering.

Particular emphasis has been placed on explaining the causes of globality of the Russian-Ukrainian conflict. The peculiarities of relations between the EU, Russia and NATO with regard to Ukraine as a sphere of their influence have been analyzed. The positive and negative aspects of diplomatic agreements (Minsk-1 and Minsk-2) regarding settlement of the Russian-Ukrainian conflict at the international level have been covered. The role of such international organizations as UN, OSCE, Council of Europe, the EU in resolving the Russian-Ukrainian conflict have been evaluated.

Key words: Russian-Ukrainian conflict; hybrid warfare; information warfare; European security; Revolution of Dignity; psychological war; geopolitical interests.

The global transformations of our age contribute to aggravation of geopolitical competition between the world's leading players and lay the foundation for large-scale geo-cultural changes. According to the forecasts of many scientists, globalization in its negative sense will promote the development of armed conflicts, religious, ideological, ethnic, racial contradictions, etc. This, in turn, will be a catalyst for change in the security guidelines of many countries $[9, \mathrm{p} .3]$. The Russian-Ukrainian conflict became particularly important against the background of these trends, which was a surprise for the Ukrainian citizens and the international community. The geographical location of Ukraine on the European continent, and numerous international treaties it signed, particularly with regard to its security, proved to be no obstacle to the armed aggression on the part of the Russian Federation. Thus, according to many analysts and scholars it confirms the crisis of the entire European security system, causes revision of its basic principles.

Many scientists now deal with studying the Russian-Ukrainian conflict. In particular, among the scientists in Ukraine and abroad the issue of hybrid war is becoming particularly relevant. Particularly significant in this context are the scientific works of P. Mansur, G. Hoffman, S. Reeves, Yu. Klymchuk, V. Horbulin, 
V. Lyvynskyi, V. Lipkan, Ye. Magda, Yu. Radkovets, A. Demidov, V. Vlasiuk. Yu. Horban studies the issues of information war, as an important component of the hybrid warfare. On the example of Russian interference in Ukraine's internal affairs, he focuses on the definition of «information aggression» concept, reviews the methods and tools of information warfare in Ukraine. The problems of information warfare have been also covered in the works by H. Pocheptsov, L. Chekalenko, M. Pashkov and others. A. Hrubinko studies the crisis of the European security system in terms of the Russian-Ukrainian conflict. The problem of the Russian-Ukrainian conflict in the context of the European security has been also highlighted in the works by A. Yermolaiev, V. Lyvynskyi, O. Lytvynenko, O. Semeniuk. It is worth mentioning at the same time that this subject needs further systematic research due to the constant aggravation of the Russian-Ukrainian conflict, violations of diplomatic agreements.

The objective of the article - to find out the features of the Russian-Ukrainian conflict («hybrid warfare») and its meaning to European security. The objective led to the following problem solving: define the causes of the Russian-Ukrainian conflict; describe the concept of «hybrid warfare»; provide its signs, methods and structural elements of Russia's hybrid war against Ukraine; consider the Russian-Ukrainian conflict in the context of relations between Russia and the EU; evaluate its degree of threat to European security; identify the ways to resolve the conflict, including through international actors.

After gaining independence, the long-lasting process of statehood formation began in Ukraine, including the transformation of both internal (economic, political, cultural) and external (formation of its foreign policy portrait and image, finding its place in the system of international relations and integration processes in particular) aspects. However, the state building processes in Ukraine proved to be quite difficult, which is largely due to the Russia's expansionist policy on the ex-Soviet area. De jure independent Ukraine enters the so-called zone of Russia's «privileged interests», which is explained by the attempts of the latter to influence the domestic policy by supporting pro-Russian leaders; aspiring to attract Ukraine to the Eurasian integration process, and, consequently, being a roadblock on its way to the European and EuroAtlantic integration, etc. We can argue that Russia's foreign policy toward Ukraine has never really envisaged the establishment of truly peer, partnership and parity relations. Instead, its goal was to turn Ukraine into a country controlled by Russia. These Russian geopolitical plans with regard to Ukraine were destroyed as a result of the Revolution of Dignity. Putin's regime in response has resorted to outright aggression against Ukraine - Crimea was annexed in March 2014, then military expansion in eastern Ukraine began. An «undeclared» or «hybrid» war of the RF against Ukraine is still going on, which causes the greatest human, territorial, and economic losses [21].

Thus, among the causes of the Russian-Ukrainian conflict the following should be singled out:

First, spreading the ideas in Russian society that Russians and Ukrainians are a single (brotherly) nation, which reunion is necessary to create the so-called «Russian world»; Ukraine is a part of Russia; Russia cannot reemerge as a world superpower without Ukraine [21, p. 29]. These anti-Ukrainian stereotypes are laid down in the 
Russian mentality, which largely determine the nature of the RF's foreign policy towards Ukraine. The latter actually is to destroy Ukraine as a national unit, the entity of international law and geopolitical reality. In this context, the words of a famous Russian geopolitician A. Dugin are worth mentioning, who believes that «the sovereignty of Ukraine is a negative phenomenon for Russia, and can easily provoke a military conflict ... Existence of Ukraine within modern borders and with the status of «sovereign state» is equivalent to crack-down on geopolitical security of Russia, intrusion into its territory. Further existence of the unitary Ukraine is unacceptable» [21, p. 29].

Secondly, the geopolitical plans of Russia for post-Soviet states, implementation of which is conditioned by activation of Eurasian integration under the auspices of the RF. In particular, the following was done:

- the Memorandum on strengthening the effectiveness of Collective Security Treaty and its adaptation to the current geopolitical situation was signed (2000);

- the Eurasian Economic Community (EurAsEC) was established (2000);

- an attempt to create a Common Economic Space (CES) (2003) with the participation of Russia, Ukraine, Belarus and Kazakhstan;

- creation of the Customs Union (2007), and general strengthening of Russia's influence on Ukraine in this context (e.g., the revised Foreign Policy Concept of the Russian Federation signed by V. Putin in 2013, where an intention has been separately stated to «build up relations with Ukraine as a priority partner within the CIS, contribute to its participation in extended integration processes» [21, p. 4]. These plans of the RF were quite realistic under the President V. Yanukovych (e.g., signing of Kharkiv agreements on April 21, 2010).

It is worth stating at the same time, that Ukraine itself contributed to strengthening of these geopolitical intentions of Russia towards Ukraine. Primarily by its policies of «multi-vectorness» or «balancing» between the two centers of power - Russia and the EU, based on actual uncertainty of its direction of integration. Europe believed this Ukrainian course was a «double game», and the Russian Federation - as a likely escape of Ukraine from the «sphere of influence». In particular, these had a negative impact on the internal development of the state, namely: the ruling clique dealt with personal enrichment by robbing the state resources; unemployment, poverty of population increased against the background of embezzlement of public resources; corruption, legal insecurity of citizens intensified, etc.

Thirdly, the revolutionary events in Ukraine in 2014 showed the aspiration of the Ukrainian people to democratic development of the country based on the European principles and, actually, proved international self-determination of the state. We should note that the Revolution of Dignity that had been taking place in Ukraine from November 21, 2013 until February 2014 has become an important stage of social and political transformations. At the same time, revolutionary changes in Ukraine have led to a tough response of the RF, which had «its own» vision of domestic and foreign political development of the Ukrainian state. The Putin Regime resorted to outright aggression against Ukraine in March 2014, Crimea was annexed, later began military expansion in Eastern Ukraine. In the consequence of Russian aggression the 
institutional mechanisms of interstate relations of both countries have been actually destroyed, political and diplomatic relations have confrontational nature and are implemented only in a multilateral format. The revolution in Ukraine also destroyed the plans of the RF to «merge» Ukraine as a «pseudo» state, carried out in the following areas: economic, energy, security and information. It is primarily about the attempts of the RF: to prevent Ukraine's rapprochement with the EU and the US, to interfere with institutional and structural modernization of the economy; to increase Ukraine's energy dependence; to shape public opinion by information policy advantageous to the Kremlin, etc. The consequences of these contradictions was that Russia refused to recognize the new state leadership of Ukraine and proclaimed the Revolution of Dignity an «armed seizure of power», «coup d'état», etc. These led to the launch of the Russian-Ukrainian conflict, which consists of the annexation of the Crimean Peninsula; deployment of military operations in eastern Ukraine; political and diplomatic confrontation; economic discrimination; energy confrontation; humanitarian aggression; information war [21, p. 11].

Scientists also attribute the following reasons for the military conflict in Ukraine as desire of some representatives of the Russian authorities to implement their imperial ambitions; bipolarity of vision of the international system; disadvantages of reforms in Ukraine; its progress in general; EU energy dependence on Russia; desire to weaken the role of the CIS countries in the EU, etc. [14].

Thus, the causes for the Russian-Ukrainian conflict are the imperial nature of Russia, the mentality of Russian society and its values, and the reluctance and disagreement of Russia with the «loss» of Ukraine.

It is worth stating that the Russian-Ukrainian conflict is now interpreted differently, often using the terms that are different from each other - the war, «hybrid» warfare, anti-terrorist operation (ATO), aggression, internal conflict, civil war. To characterize the present conflict between Ukraine and Russia we can apply the following concepts: «unconventional warfare», «irregular warfare», or «compound warfare». Common to all of these concepts is «blurring» the outlines of the military conflict and involvement of the non-military means, which are not directly related to the classic military confrontation in the ordinary state.

In our view, the most appropriate for the Russian-Ukrainian conflict is the term «hybrid warfare» that enables full comprehension of everything that happens. First of all, this is due to the fact that the historical advance of mankind, development of technological progress cause the development of weapons. At the same time, various technological innovations can now significantly affect the balance of power in international politics; question safety of many countries. Now, in terms of interdependence, increased global trends, new forms of armed struggle are emerging rather rapidly. In particular, the war goes beyond its traditional scope, is supplemented with new non-military components.

Under these conditions, the classic definition of war is changing and the traditional vision of war (way of war - actually the way of conduct of operations) is outdated and does not meet the dictates of times. Alternatively, modification of warfare led to the use of quite a new concept for scientific terminology of «hybrid» warfare. However, 
there is no definition of «hybrid warfare» in modern international law. This leads to the fact that the parties who resort to using the methods of hybrid warfare cannot be held legally accountable. Ignoring this problem by jurists may lead to ineffectiveness of the means of modern armed conflicts management.

Hybrid warfare is largely defined as a combination of classical warfare with the use of irregular armed groups. Their involvement is primarily due to the fact that they can do what ought not do the state in accordance with international principles, norms and values (i.e., the Geneva and Hague Conventions on the Laws of War on Land, agreements with other countries, etc.) [14]. The concept «hybrid warfare» is also used in the scientific literature along with the concepts of asymmetric conflicts and unconventional warfare (situations, where overt hostilities are not conducted).

The term «hybrid warfare» was first used by Frank G. Hoffman, who believed that the international conflicts would later acquire the signs of multimodality (i.e. conducted in different ways) and multivariance, i.e. would not meet traditional notions of their conduct. Moreover, the sign of hybrid warfare is also multimodality, i.e. held by the states and various non-governmental actors). [14]. He also pointed out that hybrid threats are the combination of traditional and irregular tactics and strategies of warfare; involvement of non-state actors along with the use of simple and complex technologies [3]. He noted, in particular, «... the wars of the modern era are characterized by the process of hybridization. The traditional forms of war are mixed with cyberwar, organized crime, irregular conflicts, terrorism» [31]. Hence, «hybrid threat», according to Hoffman, is any opponent, who simultaneously applies both conventional methods of warfare and acts of terrorism and criminal behavior to achieve its goals [31].

We may find the following definitions in the scientific literature:

- Hybrid warfare - a war that eliminates the distinction between conventional and irregular war; allows simultaneous use of different methods of struggle and involves adaptation of the armed forces to new conditions;

- Hybrid warfare - a war that is waged by several conflicting parties, thus it has complex nature, which requires understanding of all peculiarities (mentality, environment, etc.);

- Hybrid warfare - is a military strategy that apart from the conventional war, includes cyberwar, and envisages the use of nuclear, biological and chemical weapons, improvised explosive devices and information war;

- Hybrid warfare - is the main method of action in asymmetric warfare, which takes place among the population of the conflict zone, the rear population, and the international community [26];

- Hybrid warfare - is a purposeful process of establishing external control by one actor over another, establishing total control over the area of governance, where the information tools play a crucial role. [12] It involves everyone who has a significant impact on society (actors, singers, writers, directors, etc.) [17].

Thus, the hybrid warfare - is a war that encompasses political, cultural, humanitarian, economic and informational aspects of the society and the state functioning. Hybrid warfare has a combined nature; it envisages numerous political 
intrigues for political and economic dominance over the object of struggle. Civilians usually become the victims of such a war. In terms of such conflict, it is almost impossible to distinguish the truth from the fiction, ordinary civilians from the terrorists. Hidden foreign military intervention, which is done by the groups of militants from the neighboring countries with the support of high-tech reconnaissance and destruction means, gives this military conflict even more confusing and ambiguous nature [18, p. 36].

An important feature of hybrid warfare is that the international community faces the fact of aggression in its full denial by the very aggression. Hybrid armed forces have an advantage over traditional army, which operates within a clearly defined method.

We may state that hybrid warfare is taking place in Ukraine. This is confirmed, in particular, by peculiarities of the armed conflict progress, which distinctive feature is the lack of direct military clashes of the regular troops of Ukraine and the RF, support by the latter of the non-governmental forces (mercenaries, separatists), relations with which are formally denied. The following dirty techniques and methods of waging this war are used, like bribery, blackmail, intimidation, kidnapping, seizure of public facilities, local authorities and critical infrastructure, organization and conduct of acts of terrorism, violence and looting. At the same time, Russia, as an aggressor state, shifts the responsibility for the «dirty work» for non-state groups (including military ones) $[18$, c. 37].

Russia uses a wide range of hybrid war methods, including misrepresentation («distorting mirror»); speculations in history; denial of aggression; spreading disinformation to destabilize the situation inside the country; attempts to create a proRussian coalition in international politics. We should add an active information campaign aimed at creating a positive image of Russia in Europe; «ostensible peacekeeping» (humanitarian convoys); transfer of military equipment across the border, which is denied; involvement of Russian reconnaissance and sabotage groups; terrorist acts, etc. [14].

It is worth mentioning that the RF resorts to the use of the phenomenon of «hybrid warfare» primarily because it strives to rethink its place in the world and the region, accomplish its imperial aspirations. At the same time, nostalgia for a lost past is inherent to Russia - the period of the Soviet Union. In particular, V. Putin in his message to the Federal Assembly of the Russian Federation said, «... We have to recognize that the collapse of the Soviet Union was the greatest geopolitical catastrophe of the century. It was a real drama for the Russian people. Tens of millions of our fellow citizens and countrymen found themselves outside the Russian territory».

Scientists agree that under the changed rules of game for international relations of the Russian Federation in the accomplishment of its imperial ambitions (a relic of the past) asymmetric approach is only appropriate. After all, if they act according to all rules and principles of international life, the ideas of «Russian world» and the Great Russia would obviously be never implemented. The period from 2001 till 2014 is considered a phase of search for forms and methods for implementation of geopolitical 
plans. In particular, a priority task for the Russian government was to start training its own population or «geopolitical mobilization» of the population of the state. First of all, it envisaged imposing an image of «foreign enemy» on its own people, shaping a clear distinction between «I» and «Other».

The change of political regimes in the CIS (Georgia, Ukraine, Moldova, Kirghizia) made the RF prepare for the opposition more intensively to «defend» its interests. Since the domestic political changes in the former republics were perceived by the RF as an external threat to realization of its geopolitical goals.

Apart from purely political and military methods, Russia used the concept of the «war of three quarters» within «hybrid warfare». Its essence is to ensure that the contemporary military person has to conduct a traditional battle in one quarter, fulfill police functions in the second one, and carry out a humanitarian mission in the third one. «Green men» were the first to appear in Crimea, whose main task was the implementation of «humanitarian» mission to ensure «the rights of Russian-speaking population». Later they moved to the functions of police, namely assistance in holding «referendum». Then they performed quasi-military functions on forceful imposition of fulfillment of the «referendum» results.

The most important component of waging Russia's «hybrid war» against Ukraine, in our opinion, is information one. Active use of the information front is primarily due to the fact that it is used among the population in the conflict zone; among the population of the country, against which the aggression is exercised, but which territory is not covered by the conflict; among the citizens of the aggressor country and the international community. Thus enables quick impact on the minds of all parties to the conflict.

Simulacra have become an important component of information war - images of what does not exist in reality. Examples of such simulacra are «fascists in Kyiv», «atrocities of punitive battalions», «crucified boys», the Ukraine's use of the banned weapons. The strategic goal of use of these simulacra is to replace fair presentation of the nature of conflict by the «Information phantoms» that are beneficial for the aggressor.

In this case, it should be noted that to support its actions the aggressor uses the methods of «hybrid warfare» against its citizens as well. As a result, many Russians trust the information advocacy of their authorities.

The RF is trying hard to convince the international community in its propaganda. It uses the activity of different «think tanks», fictitious pro-Russian «experts» in Europe, as well as the activity of the RT channel. One must constantly give opposing arguments to counteract this.

Now the European countries are also worried with the scale of the Russian information penetration. NATO Strategic Communications Centre of Excellence was established in Latvia in 2014, which tasks include - provide an adequate response to the attempts of other countries to influence the NATO information space. The importance of strategic communications development was emphasized after the NATO Summit in Wales. In particular, it has been explicitly stated there that the established Centre should take care of the issues of «hybrid warfare». Some countries, 
including Poland and the Baltic States, hope for the positive activity of the Centre in counteracting the Russian propaganda.

The distribution of Russian propaganda is actively done through a worldwide network «Internet» too. In particular, special psychological operations are conducted in social networks [6].

The US National Institute for Strategic Studies and some Western experts and scholars distinguish the following components of information warfare:

- psychological warfare with the aim of bringing the ideas and opinions required by Kremlin into a social and individual consciousness. In particular, it envisages disorientation of population; intimidation of its people by an image of enemy, while the opponent with its own power; propaganda of its ideas by various ways. They include the messages that are distributed to generate a positive perception of certain actions in public opinion, provoke certain emotions, attitudes, political behavior among population, which are beneficial for the facilitator. The following basic methods of information aggression are distinguished within Russia's hybrid war against Ukraine: 1) misinformation and manipulation; 2) advocacy; 3) diversification of public opinion; 4) psychological and psychotropic pressure; 5) rumormongering [5, p. 138].

At the same time, it is worth pointing out that the Russian-Ukrainian conflict is not a «local», «peripheral» event - it has regional and global dimensions and includes challenges and threats to the global security system [1]. The grounds should be considered the following:

- first, the EU strongly promoted a number of initiatives of integration and approximation. For example, the European Neighborhood Policy in Eastern Europe (Ukraine, Belarus, Moldova) was in 2003. The development of relations between the EU and Russia was also a part of the movement towards a common space.

Instead, a desire to restore its sphere of influence in the European continent has become important to the RF. A period of «political and economic domination» and control over «zones of exceptional geopolitical interests» began in relations between the EU and Russia. The European Union began to noticeably tend to the Euro-Atlantic vector of development and execution of the Transatlantic Economic Zone with the United States. Russia in its turn, especially after the Cyprus crisis, began to bet on the development at the expense of mobilization and etatisation of economy. However, the RF leadership sought to compensate a threat of drop-out from the European market by accelerated entering the markets of the PRC and Southeast Asian countries. Thus, the $\mathrm{EU}$ and the RF quite quickly turned from protagonists - the two centers of a single integration process, - into antagonists, which compete for the spheres of influence [9, p. 6-7].

Different perception of international processes in the EU, the US and the RF also contributed to complication of relations. Thus, democratic values and principles of liberal ideology in general are a priority for the West. Instead, the Russian government is guided by the ideological tenets of the late XIX century. This generates different views of the same processes. For example, the Russian Federation failed to understand that Ukraine's entrance to the EU and NATO is not directed against Russia [11, p. 32]. 
The two centers of power did not leave the issue of Ukraine's integration in this aspect aside.

Russian-Ukrainian conflict has actually become a new springboard for competition of the EU and the RF for the spheres of influence. As a result, the European security system and the system of international relations in general entered a period of sharp aggravation of latent crisis. The confrontation of powerful geopolitical players - the core subjects of the European security system (the USA, NATO and the EU on the one hand, Russia - on the other hand) on the example of Ukraine repeatedly showed unsolved problems and miscalculations in the policy of «Western democracies» for the period of post-bipolar world order. We should single out the following among them:

- uncertainty of further development of the system of Euro-Atlantic relations, the US role in provision of the European security, the EU capabilities in reaching a consensus, the ability to act as a single center of international policy;

- lack of adequate strategies of western structures with regard to inadequate strengthening of the monopoly energy and military-political resources of Russia, which entails its openly aggressive foreign policy and disregard of the basic rules of international law [7, c. 232];

- underestimation by West of the situation of the former Soviet Union states, including Ukraine, and Russia's imperial ambitions. They obtained a status of relatively affluent buffer areas with prospects of democratic development. The US and Western Europe actually «gave» Russia the territories of its traditional geopolitical influence (except Baltic states) subject to the introduction of a market economy, democratization of social relations and forms of state [7, p. 238].

The military aggression of the RF against Ukraine, the annexation of Crimea demonstrated weakness of the West in its relations with Russia. Only because of the tragedy of the liner «Boeing 777» in July over Donetsk region, and then entering the regular units of the RF Armed Forces on the territory of Ukraine, the EU Council after continued hopes for appeasement of the aggressor by means of diplomacy took the decision to impose system sanctions (the so-called sanctions of the «third wave»). Subsequently, F. Mogherini, the High Representative of the Union for Foreign Affairs and Security Policy, announced about termination of the partnership relations of the EU with Russia. NATO Secretary General Anders Fogh Rasmussen also said that NATO and Russia are no longer the partners, but the opponents.

However, it should be understood that the EU in the sphere of security cannot offer Ukraine anything but the traditional methods of «soft power», the prospects for economic assistance and anti-Russian sanctions that will have the long-term consequences, tough statements and public condemning of the actions of the aggressor. The support of the US and NATO is more likely for Ukraine. However, none of the partners of Ukraine is in hurry to provide offensive weapons in hopes of de-escalation of the conflict. It should be also understood that the pro-Russian lobby works in the EU and NATO. For example, Austria, Finland, Hungary and Slovakia are against introduction of sanctions. In September 2014, at the height of the Russian aggression in eastern Ukraine the European Commission in favor of trade and 
economic interests of Russia decided to postpone the entry into force of the Agreement on free trade between the EU and Ukraine. Critics are unanimous with regard to slowness of the EU actions. However, the existence of threats to the EuroAtlantic security of the EU and NATO does not help Ukraine to obtain clear prospects of membership.

However, the Russian-Ukrainian conflict may:

- become a powerful incentive to spread the influence of NATO on the global politics. The Alliance may find its role of military stay in Europe, which it lost at the end of the «Cold War»;

- restore the functions of deterrence of war in Europe. This will mean the need for reorientation of its military power to perform complex tasks of defense and increase of preparedness to broad strategic confrontation. It is especially necessary for the defense of Central and Eastern Europe [7, p. 240-245].

The Russian-Ukrainian conflict actually showed that the current system of international security is barely able to respond to the crisis, initiated by terrorist, extremist and fundamentalist movements. Assistance to countries in the fight against terrorism and extremism is largely in bilateral or block formats. The capabilities of the international security system to respond to challenges of economic, information, resource and humanitarian security of individual countries seem to be insufficient and limited. This greatly reduces the capacity of international institutions in settlement of «hybrid» conflicts and preventing them from escalating into an open phase. In terms of deployment of the next wave of global economic crisis and growing conflicts between the major world powers, regional leaders, blocks of states, such a weakness of international and regional security institutions is a threat by itself. The lack of reliable safeguards for proliferation of conflict increases the risks of new large-scale armed confrontations [9, p. 6-7].

As for the settlement of the Russian-Ukrainian conflict, it should be stated that a series of diplomatic arrangements have been carried out at the international level, which, however, proved to be ineffective and inefficient in practice.

First, the four-party negotiations were held on settlement of the armed conflict between Russia and Ukraine with the participation of senior diplomatic representatives of Ukraine, the EU, the USA and Russia in Geneva on April 17, 2014. After hours of discussions, agreements were reached at the meeting on release of the seized buildings in Ukraine and amnesty of the protesters. The US, the EU and Russia pledged to support the Special Monitoring Mission of the OSCE, which will play a leading role in promoting the Ukrainian authorities and local communities in the immediate implementation of measures aimed at de-escalation of the situation. Western countries suspended the introduction of additional economic sanctions against Russia, which they were getting ready to introduce in case of a failure of the Geneva talks.

«Geneva format» of negotiations, in particular, envisaged the measures for deescalation of the conflict in Donbas - disarmament of illegal armed formations; amnesty to separatists; launch of the national dialogue in Ukraine on the constitutional reforms that would envisage decentralization and granting a temporary special status to Donbas [27]. 
At the same time, it should be noted that the Russian party in Geneva began a double game, which aim was not to find acceptable ways of settlement to all parties, but to deny its participation in the aggression, disguise forceful imposition of terms of conflict settlement on Ukraine, which are harmful for its statehood, legalize quasistate entities «DPR» and «LPR», mislead the international community about the nature and causes of the situation, generated by the Russian aggression. That is why all the attempts to stop Russian aggression by diplomatic means and peaceful initiatives in future formats yielded no positive results.

Russia violated the agreements recorded in the Geneva statement dated April 17, 2014 on de-escalation of tension, disarmament of illegal armed groups, return of illegally seized premises to their lawful owners, as well as support of the work of the OSCE Special Monitoring Mission. In addition, the RF ignored the peace plan of the President of Ukraine Petro Poroshenko, which was unilaterally implemented since June 20 for seven days and continued for three more days. The plan envisaged that the parties should cease fire and withdraw illegal armed groups from Ukraine through the guaranteed security corridor, exempt from criminal liability those who surrendered and did not commit a serious crime, initiate decentralization and recovery program in Donbas in Luhansk oblasts.

On June 25, 2014 the Federation Council of the Russian State Duma adopted a resolution on withdrawal of the President's authorization to use the RF Armed Forces in Ukraine, the Russian party not only took no measures to cease fire, but intensified armed support of the groups of its mercenaries and increased the presence of its armed forces in Ukraine and at the Ukrainian-Russian border.

It should be pointed out that the change of the negotiations format took place upon the RF's initiative, namely the establishment of the Trilateral Contact Group comprising representatives of the OSCE, Ukraine and Russia. Thus, the participant of negotiation process has become the OSCE instead of the US and the EU, which significantly weakened Ukraine's position.

An important thing was that it was agreed «to terminate the use of weapons» on September 5, 2014 in Minsk, which was formally recorded in the Protocol following consultations of the Trilateral Contact Group on joint steps aimed at implementation of the peace plan of the President of Ukraine P. Poroshenko and initiatives of the President of Russia V. Putin. This was the so-called «Minsk-1» (consisting of 12 clauses). The document was signed by the members of the Trilateral Contact Group - Ambassador Heidi Tagliavini (on the OSCE part), the second President of Ukraine Leonid Kuchma, and Russian Ambassador to Ukraine Mikhail Zurabov. The document was also signed by representatives of the so-called DPR and LPR, but without reference to their status and positions.

Due to the fact that the parties to the conflict were on the verge of the full-scale war, a new attempt to resolve the conflict was the talks in «Normandy Format» in Minsk or «Minsk-2». A Package of Measures was concluded according to its results aimed at implementation of the Minsk Agreements.

While the «Geneva format» of talks includes the USA, the EU, Ukraine and Russia, the participants of the «Normandy format» were Germany, France, Ukraine 
and Russia. There are ongoing debates until now, which format of talks - «Geneva» or «Normandy», is better to resolve the Russian-Ukrainian conflict.

Let us note that the agreements of «Minsk-2»- is an updated tool for resolving the problems on the territory of Ukraine. Despite quite positive evaluations among political analysts and experts, one should understand that the signed documents do not guarantee conflict resolution on their own. The issue of their implementation is important, which remains an open question until now.

Having analyzed statements and expressions from all parties to the «Normandy Quartet», we may claim that the «Minsk-2» is a kind of compromise within the Russian-Ukrainian conflict between the West and the RF, since the West is not ready for a tougher stance with respect to the RF.

Ukrainian and European media unanimously claim that no clause of the «Minsk2» agreement has been $100 \%$ satisfied, since the agreement is violated every day. We should not forget that after signing of the agreements militants seized Debaltseve and conducted sporadic armed operations against Ukraine (city Marinka). In particular, heavy artillery was not withdrawn from the boundary line. The work of the OSCE mission (and this is the third clause of the agreement) also creates more questions than answers. The militants do not allow the representatives of the organization to the whole territory under their control, which greatly complicates the objectivity of their assessments. Since the withdrawal of heavy equipment has not yet happened, the issue of elections is not discussed at the appropriate level as well (clause 4 of the agreement). The law of Ukraine on amnesty for separatists has not entered into force (clause 5), which is, beside, ambiguously perceived by the Ukrainian society. Exchange of prisoners (clause 6) also remains largely ignored.

Moreover, clauses of the agreement regarding access of humanitarian aid, withdrawal of all foreign armed units, military equipment and mercenaries from the territory of Ukraine under the supervision of the OSCE, etc., are not met. Instead, Russia continues to insist that there are no regular troops on the territory of Donbas.

The inefficiency of the Minsk agreements, according to analysts of today, is that:

- There is no clear understanding of the situation that is happening. What it involves is the fact that the subjects of international negotiations are the officials of several countries. Thus, the negotiating table unites the state-victim Ukraine and the state-aggress or Russia, which does not officially recognize the presence of its troops in eastern Ukraine, but supports the actions of terrorist groups, gives them economic, political and humanitarian support. The actions of these entities and international crimes committed by them with certain practices in Ukraine give grounds to say that they should be considered as terrorist, and Russia should be perceived as a country that finances terrorism. Ukraine and Russia are signatories of international treaties of questionable legal nature (international treaty or international political agreement) and questionable nature of international legal obligations under these agreements (Russia is known for its special attitude to its obligations by the general international law and the Minsk agreements).

- There is some uncertainty on the part of Ukraine as well with regard to perception of the situation. At first, Ukraine states that it conducts anti-terrorist 
operation, and later that the territories in eastern Ukraine are occupied not by «DPR» and «LPR», but by Russia. Along with the recognition of the fact of occupation, Ukraine recognizes Russia an aggressor-state, but does not declare martial law in Ukraine. It is complemented with a fact that, actually, armed opposition of the ATO forces and terrorist groups under the Russia's control, is classified either as noninternational armed conflict (then we deal with the rebels, who took up arms and have a status in accordance with international law) or international armed conflict (i.e. armed conflict between Ukraine and Russia, which began with the aggression in Crimea and continued with aggression in the east), or a combination of international and non-international armed conflict (since there is no such term as «hybrid warfare» in the international law).

- Ukraine is simultaneously imposed with a though that it should conduct a direct dialogue with the «DPR» and «LPR», i.e., with the terrorist organizations. In particular, the agreements provide amnesty to terrorists (who committed not only terrorist attacks combined with war crimes and crimes against humanity, but also other violations of human rights, such as kidnapping, human trafficking, torture and others dehumanizing treatments). The members of this conflict and the European partners of Ukraine might have created with all these the most powerful political and legal uncertainty web of international law in history.

- agreements have unclear legal nature. First of all, there is no unambiguous interpretation of what exactly the «Minsk-2» agreements are from the point of view of international law, and each party may interpret them according to their own interests and the current political environment.

- Lack of understanding of the exact content of the agreements, which leads to considerable speculations in the media space, creates additional tension around them, and pressure on the parties.

- Minsk documents do not establish any sequence or timing of withdrawal of all foreign armed groups, illegal armed units, military equipment, as well as militias and mercenaries from Ukraine (cl. 10 of the Protocol and cl. 9 of the Memorandum). But clauses 3, 6 and 9 of the Protocol envisaged the adoption of the Law of Ukraine «On the temporary order of local self-government in separate regions of Donetsk and Luhansk Oblasts» (the law on the special status), the Law of Ukraine «On preventing persecution and punishment of participants of events on the territories of Donetsk and Luhansk Oblasts» and early local elections according to the law on special status.

Let us note that the introduction of a special order of local self-government in separate regions of Donetsk and Luhansk Oblasts, where armed formations of Russian mercenaries and units of the regular Armed Forces of Russia are still present, will actually legalize self-proclaimed quasi formations of «DPR» and «LPR» and «freeze» the conflict.

Many analysts now do not rule out the idea that the Minsk Protocol has become the result of backstage international agreements between the highest leaders of Ukraine, Russia and leading Western countries. However, this is a reason to violate the requirements of international law by the RF. According to the principle of the indivisibility of international agreements, which is generally recognized in 
international law, particularly in the Law of Treaties, selective implementation of the treaty provisions by the parties is unacceptable. Any international treaty is enforceable as a single system whole; its provisions are interrelated and interdependent and should not be applied selectively [20, p. 32-34].

To improve the efficiency of the negotiation process on resolving the armed conflict in eastern Ukraine, the experts suggest:

- Change the format and membership of the talks;

- Attract representatives of the United States and/or Poland;

- Clearly define the legal form of negotiations and status of their participants in terms of international law that will allow applying international legal instruments at their subsequent implementation;

- Ensure transparency and openness of information on the agreements reached, which will benefit the increase of the efficiency of their performance monitoring, etc.

Apart from negotiations at the diplomatic level, numerous international organizations, both governmental and non-governmental, have been attracted to resolve the Russian-Ukrainian conflict. According to the current requirements of international law, critical situation in Ukraine can only be settled through mediation of international organizations. International organizations are a tool for early detection, warning and prevention of conflicts, crisis management and post-conflict rehabilitation; they are engaged in a wide range of security issues, including arms control, preventive diplomacy, measures for confidence-building, human rights, monitoring the elections, economic and environmental safety, etc. [9, p. 125].

Let us consider the work of the UN, the OSCE, the Council of Europe and the EU.

The primary place in the order of settlement of the armed conflict in the southeast of Ukraine belongs to the key intergovernmental international organizations that deal with peace and security in the world - the United Nations Organization and the Organization for Security and Cooperation in Europe.

It is worth mentioning that the UN was founded in 1945 to maintain international peace and security, develop friendly relations among nations and promote social progress, better living standards and human rights. It unites 193 states.

The activity of the UN Security Council on maintaining peace and security is to:

- determine sanctions against states-violators (including military operations against them);

- introduce peacekeeping forces in the conflict zone;

- arrange post-conflict settlement, in particular, introduce international administration in the conflict zone.

However, the UN Charter contains the restrictions on settlement of the armed conflict on the territory of Ukraine. Thus, according to the Charter of the Organization, the Security Council consists of five permanent members (Great Britain, Russia, People's Republic of China, the USA, and France) and 10 non-permanent, which the UN General Assembly elects on geographical basis.

The decision of the Security Council (other than procedural) require nine votes out of fifteen, including the concurring votes of the permanent members. This means that each of the five permanent members of the Security Council has the right to veto 
decisions of the Council. Therefore, the RF will always have the right to veto all the UN actions aimed at escalation of the armed conflict in Ukraine.

The new National Security Strategy of Ukraine as of May 6, 2015 states that the aggression of Russia against Ukraine has increased the urgency of reforming the UN Security Council. Within the framework of the UN General Assembly, attention of the Government of Ukraine will focus on supporting such initiatives on reforming the UN Security Council that will ensure its adequate response to violations of international law, even if the offender is a permanent member of this body.

With this in mind, the main role in resolving the armed conflict in Ukraine belongs to the OSCE.

OSCE - is the world's largest regional security organization. The Conference on Security and Cooperation in Europe (CSCE) was established in 1975. The CSCE has acquired the official status of an international organization and was renamed as the OSCE in January 1995. The organization includes 57 member states from North America, Europe and Central Asia with a common approach to security in its three dimensions - politico-military, economic and environmental, and human. The feature of this Organization is the presence of field operations that operate directly in some member states and, upon their request, provide the necessary assistance $[9$, p. 128129].

After the change of power in February 2014 and the annexation of Crimea, the role of OSCE significantly increased with regard to easing tensions between Ukraine and Russia and promotion of peaceful settlement of the conflict in eastern Ukraine. In connection with the referendum in Crimea on secession from Ukraine, which was not agreed with the Ukrainian authorities, the government appealed to the OSCE on March 16 to urgently send a monitoring mission to Ukraine to track the facts of aggression and illegal foreign interference. On March 21, 2014, the OSCE Permanent Council on the basis of the request of the Ukrainian government decided to establish the Special Monitoring Mission (SMM) in Ukraine, the mandate of which extends throughout the state. The purpose of the OSCE mission in Ukraine is to maintain dialogue and reduce tension in the country.

However, many analysts are rather skeptical today about the activities of the OSCE mission, emphasizing the limitations of its activities. However, it should be understood that the OSCE is not peacekeeping, and its SMM representatives are unable to control the situation on the entire length of the border of the conflict zone.

The European Union - is an organization, which the authorities and ordinary citizens in Ukraine confer almost the greatest expectations. The experts note in particular that the EU bears also a moral responsibility for solving the RussianUkrainian conflict, since the desire of Ukrainians to join the EU contributed to the Maidan.

The EU implements its support in the following areas:

- Support in implementing economic and political reforms;

- EU - the main source of economic aid to Ukraine via different institutions - the IMF, World Bank and others;

- Sanctions by which European politicians expect to put pressure on Russia. 
However, we can state that the EU is unable to combine the positions of its member states on the situation in Ukraine. For example, among the opponents of sanctions one most often call the Czech Republic, Greece, Cyprus, France, Hungary and Italy. On the other hand, some experts doubt the effectiveness of the EU economic mechanisms, at least, if applied to the current Russian regime [29].

The Council of Europe $(\mathrm{CoE})$ - is an international organization of 47 member states in European space. Membership is open to all European states that recognize the rule of law and guarantee fundamental human rights and freedoms for its citizens. One of the greatest successes of this Council is the Convention on Human Rights and Fundamental Freedoms 1950, which serves as the basis for the European Court of Human Rights. The headquarters of the Council of Europe is in Strasbourg on the French-German border. One of the major statutory bodies of the Council of Europe is the Parliamentary Assembly of the Council of Europe. It is chiefly an advisory body made up of members of parliament of all states parties.

Regarding the conflict in Ukraine, it is worth mentioning that the PACE does not hide its pessimistic assessments in its resolution. In particular, within the session of this organization a hearing has been recently held on «The conflict in eastern Ukraine: political and humanitarian issues». The emphasis was that:

- The conflict in eastern Ukraine has significantly increased, and in the present situation we cannot talk about holding elections in Donbas in the nearest future;

- The current state of affairs in the occupied territories was called a «hybrid annexation», which was the inevitable consequence of a hybrid war waged by Russia against Ukraine;

- Europe is not enough interested in what happens to the displaced people in Ukraine.

In addition, the Parliamentary Assembly of the Council of Europe adopted a resolution, which called on all parties to the conflict in Ukraine to release prisoners. «PACE urges Ukraine, the Russian Federation and the separatist groups to stop all military operations in eastern Ukraine, withdraw all weapons and restore peace in this region, respect international humanitarian law and grant international humanitarian organizations access to all detainees». However, it should be mentioned that the $\mathrm{CoE}$ and its Parliamentary Assembly (PACE) primarily carry out diplomatic functions as a platform for discussion. However, after Russia suspended its participation in the Council of Europe by the end of 2015 - it is difficult to say that the CoE can somehow influence the situation.

Overall, despite sharp international political crisis caused by events in eastern Ukraine, conviction by the majority of states of the illegal annexation of Crimea and presence of the Russian armed forces in the territory of Ukraine, the position of international organizations clearly emphasized peaceful settlement of the conflict in Donbas. We can point to several reasons that cause the restraint of international organizations with regard to provision of necessary support to Ukraine. They primarily have to do with the reluctance of the EU and the US to take steps that threaten aggravation of their relations with the RF to the level of military confrontation. We should not disregard the factors of difficult economic interdependence that make the 
use of the full-scale economic sanctions tangible not only to the countries, against which they are directed, but also to their initiators. Finally, the Western powers have been trying to realistically evaluate the existing tools that they could apply to deescalate the conflict [24, c. 14].

Considering the above, it should be emphasized that the resolution of the RussianUkrainian conflict needs to find other mechanisms, ones that are more effective. On the one hand, there were many attempts to resolve the conflict through various international actors, on the other hand - geopolitical features of current international relations (Russian intentions, the confrontation between Russia, the EU and the US, where the RF has an advantage by ignoring the international law and insufficient response of other actors to that) creates new challenges for the security of many countries.

Thus, Russia wages hybrid war against Ukraine with the use of a broad range of methods. The hybrid warfare - is a war that combines classical (with the help of the military personnel and weapons) and advanced (using irregular armed groups) ways of waging, and other forms and methods of inflicting substantial losses to enemy economic, energy, environmental, coupled with the use of powerful information and cyber attacks. An important feature of hybrid warfare in Ukraine is a public «noninvolvement» of the RF in the conflict. Experts call the hybrid warfare a type of conflict that is increasingly used in the $21^{\text {st }}$ century. The goal of hybrid warfare is primarily a combination of foreign aggression and domestic destabilization to destroy the enemy or force him to take the decisions necessary to the aggressor.

Given the global trends of international relations, the Russian-Ukrainian conflict threatens the security of the whole Europe. Consequently, the RF and the EU gradually develop to competitors for the spheres of influence. The important tasks for Ukraine should become generation of the concept of hybrid warfare counteraction; defining the principles of public administration in terms of hybrid warfare; studying the possible scenarios of situation development and using counteractions; creation of a new National Security Doctrine of Ukraine; modernization of information security system, etc.

\section{REFERENCES}

1. Аналіз діалогових ініціатив щодо врегулювання конфлікту в Україні. Національний діалог [Електронний ресурс] // Міжнародний центр політичних досліджень. - 2015. - 63 с. - Режим доступу : http://icps.com.ua/assets/uploads/files/mapping_of_dialogue_initiatives_ukr_.pdf

2. Безпекова політика України в контексті формування системи колективної безпеки в Європі [Електронний ресурс]. - Режим доступу : http://www.niss.gov.ua/articles/421/

3. Власюк B. B. Деякі основи поняття «Гібридна війна» в міжнародному праві [Електронний ресурс] / В. В. Власюк, Я. В. Карман // Право і громадянське суспільство. - 2015. № 1. - С. 226-234. - Режим доступу : http://lcslaw.knu.ua/2015-1.pdf

4. Врегулювання конфлікту на Донбасі має відбуватися у різних форматах переговорів [Електронний pecypc]. - Режим доступу : http://www.razum-kov.org.ua/ukr/article.php?news_id=1190

5. Горбань Ю. О. Інформаційна війна проти України та засоби ії ведення [Електронний ресурс] / Ю. О. Горбань // Вісник НАДУ. - 2015. - № 1. - С. 136-141. - Режим доступу http://visnyk.academy.gov.ua/wp-content/uploads/2015/04/20.pdf

6. Горбулін B. «Гібридна війна» як ключовий інструмент російської геостратегії реваншу 
[Електроний ресурс] / В. Горбулін // Деркало тижня. - 2015. - № 2. - Режим доступу : http://gazeta.dt.ua/in-ternal/gibridna-viyna-yak-klyuchoviy-instrument-rosiy-skoyi-geostrategiyi-revanshu-_.html

7. Грубінко A. Криза системи європейської безпеки в умовах російсько-українського конфлікту: стратегічні підходи та інтереси Великої Британії [Електронний ресурс] / А. Грубінко // Міжнародні зв'язки України: наукові пошуки і знахідки. - 2015. - Вип. 24. - С. 232-250. - Режим доступу : http://nbuv.gov.ua/UJRN/Mzu_2015_24_16

8. Євтушенко I. В. Роль та місце міжнародних організацій у врегулюванні збройного конфлікту на південному сході України (нормативно-правовий аспект) [Електронний ресурс] / I. В. Свтушенко // Кримінальне право та кримінологія; оперативно-розшукова діяльність. - 2015. С. 124-132. - Режим доступу : http://plaw.nlu.edu.ua/article/viewFile/55264/54905

9. Єрмолаєв A. Український конфлікт і майбутнє світової та європейської безпеки [Електронний ресурс] / А. Срмолаєв, С. Денисенко, О. Маркєєва, Л. Поляков // Нова Україна. Інститут стратегічних досліджень. - 2015. - Режим доступу : http://newukraineinstitute.org/ media/news/501/file/crisis_se-curity\%20UKR.pdf

10. Ливинський В. Війна цивілізацій, або глобальні аспекти конфлікту на Донбасі [Електронний ресурс] / В. Ливинський // Зовнішні справи. - Режим доступу : http://uaforeignaffairs.com/ua/blog/usi-blogi/view/article/viina-civili-zacii-abo-globalni-aspektikonfliktu-na/

11. Литвиненко O. Європейська безпека і Україна: можливий шлях послабити виклики і загрози [Електронний ресурс] / О. Литвиненко // International Review. Відносини Україна-СС: в пошуках нової системи європейської безпеки. - № 3 (11). - 2009. - С. 30-38. - Режим доступу : http://library.fes.de/pdf-files/bueros/ukraine/06780/review-3.2009.pdf

12. Ліпкан В. А. Сутність гібридної війни проти України [Електронний ресурс] / В. А. Ліпкан // Глобальна організація союзницького лідерства. - Режим доступу : http://goal-int.org/sutnistgibridnoi-vijni-proti-ukraini/

13. Магда Є. В. Гібридна війна: вижити і перемогти / С. В. Магда. - Х. : Віват, 2015. - 304 с.

14. Магда $\epsilon$. Виклики гібридної війни: інформаційний вимір [Електронний ресурс] / Є. Магда. - Режим доступу : irbis-nbuv.gov.ua/.../cgiirbis_64.exe?...

15. Микитишин O. Мінськ-2: політико-правовий присмак неефективності [Електронний pecypc] / О. Микитишин. - Режим доступу : http://iac.org.ua/minsk-2-politiko-pravoviy-prismakneefektivnosti/

16. Пашков M. Російсько-український конфлікт: фактор відчуження [Електронний ресурс] / М. Пашков // Агора. - № 15. - С. 21-26. - Режим доступу : http://www.uceps.org/upload/1450445630_file.pdf

17. Почепиов Г. Гібридна війна: інформаційна складова [Електронний ресурс] / Г. Почепцов // Незалежний культурологічний часопис «̈̈». - Режим доступу : http://www.jimagazine.lviv.ua/2015/Pochepcov_Gibr_vij-na_inf_sk-ladova.htm

18. Радковець Ю. «Гібридна політика» сучасної Росії як стратегія реалізації її національної геополітики [Електронний ресурс] / Ю. Радковець // Борисфен Інтел. - Режим доступу : http://bintel.com.ua/uk/article/gibrid-politics/

19. Радковець Ю. I. Ознаки технологій «гібридної війни» в агресивних діях Росії поти України [Електронний ресурс] / Ю. І. Радковець // Наука і оборона. - 2014. - № 3. - С. 36-42. Режим доступу : http://www.nio.mil.gov.ua/pdf/2014-3.pdf

20. Російсько-українська війна 2014 року: причини, перебіг та політико-правові оцінки [Електронний ресурс] // Український тиждень. - 2014. - № 42(362)17. - С. 28-43. - Режим доступу : http://i.tyzhden.ua/content/pho-toal-bum/2014/10_20-14/17/26-42.pdf

21. Російсько-український конфлікт: стан, наслідки, перспективи розвитку подій [Електронний ресурс] // Національна безпека і оборона. - 2014. - № 5-6. - С. 2-19. - Режим доступу : http://www.razum-kov.org.ua/ukr/fi-les/ca-tegory_journal/analytic_5_6_Ukr_Ros_2014_ site_s.pdf

22. Секунданти війни на Донбасі. П’ять претензій до ОБСЄ [Електронний ресурс] // Режим доступу : http://espreso.tv/article/2016/03/15/sekundanty_viy-ny_na_donbasi_pyat_pytan_do_obsye

23. Семенюк $O$. Нова архітектура європейської безпеки: тенденції, виклики, перспективи [Електронний ресурс] / О. Семенюк // International Review. Відносини Україна-СС: в пошуках 
нової системи європейської безпеки. - 2009. - № 3(11). - С. 4-14. - Режим доступу : http://library.fes.de/pdf-files/bueros/ukraine/06780/review-3.2009.pdf

24. Толстов C. Діяльність міжнародних організацій в Україні: загальні тенденції та орієнтири / С. Толстов // Віче. - 2015. - № 4. - С. 11-14

25. Федір Брецко : метою цієї війни є повне підпорядкування України експансіоністським неоімперським планам Кремля [Електронний ресурс]. - Режим доступу : http://prozak.info/mobile/ Suspil-stvo/Brecko-pro-gibridnu-vijnu-Rosiyi-proti-Ukrayini

26. Чекаленко Л. Про поняття «гібридна війна» [Електронний ресурс] / Л. Чекаленко // Віче. - 2015. - № 5. - Режим доступу : http://www.viche.info/journal/4615/

27. Ще раз про формати і альтернативи (у контексті припинення війни на Донбасі) [Електронний ресурс] // Незалежний аналітичний центр геополітичних досліджень. - Режим доступу : http://bintel.com.ua/uk/article/format/

28. Що відбувається на Сході України. Ще раз про термінологію [Електронний ресурс] // Режим доступу : http://osvita.mediasapiens.ua/media_law/law/sc-ho_vidbuvaetsya_na_skhodi_ukraini_ sche_raz_pro_terminologiyu/

29. Яку роль відіграють західні організації у врегулюванні конфлікту на Донбас [Електронний ресурс]. - Режим доступу : http://ukr.segodnya.ua/politi-cs/pnews/kakuyu-rol-igrayutzapadnye-organizacii-v-uregulirovanii-konflikta-na-donba-sse-589728.html

30. Яременко Б. Мінські домовленості - розв'язання конфлікту чи рецепт катастрофи? [Електронний ресурс] / Б. Яременко // Хвиля. - Режим доступу : http://glavcom.ua/columns/ bogdanyaremenko/330649-minski-domovlenosti-\%E2\%80\%93-rozv\%E2\%80\%99jazannja-konfliktu-chiretsept-katastrofi.html

31. Hoffman F. G. Hybrid Threats: Reconceptualizing the Evolving Character of Modern Confict [Electronic resource] / Frank G. Hoffman // Strategic Forum ; Institute for National Strategic Studies National Defense University. - April 2009. - № 240. - Mode of access : http:// http://www.ndu.edu/inss

Стаття надійшла до редколегії 29.04.2016

Прийнята до друку 15.05.2016

\title{
МІЖНАРОДНИЙ ВИМІР ЗБРОЙНОГО КОНФЛІКТУ НА ПІВДЕННОМУ СХОДІ УКРАЇНИ
}

\section{Наталія Антонюк, Маркіян Мальський}

\author{
Львівський національний університет імені Івана Франка, \\ вул. Університетська, 1, м. Львів, Україна, 79000, тел. 032-239-46-56, \\ e-mail:nantonyk@yahoo.com; malskyy@ispc.org.ua
}

У статті здійснено аналіз особливостей російсько-українського конфлікту («гібридної війни») та з'ясовано його значення для європейської безпеки. Зокрема, висвітлено причини російськоукраїнського конфлікту. Охарактеризовано поняття «гібридної війни», іiї ознаки, методи, структурні елементи. Обгрунтовано використання терміна «гібридна війна» для українських реалій. Значну увагу приділено інформаційному елементу гібридної війни в Україні.

Особливий акцент зроблено на поясненні причин глобальності російсько-українського конфлікту. Проаналізовано особливості відносин між ЄС, Росією та НАТО щодо України Висвітлено позитивні та негативні аспекти дипломатичних домовленостей (Мінськ-1 та Мінськ-2) щодо врегулювання російсько-українського конфлікту на міжнародному рівні. Оцінено роль міжнародних організацій у врегулюванні російсько-українського конфлікту.

Ключові слова: російсько-український конфлікт; гібридна війна; інформаційна війна; європейська безпека; революція Гідності; психологічна війна; геополітичні інтереси. 


\section{МЕЖДУНАРОДНОЕ ИЗМЕРЕНИЕ ВООРУЖЕННОГО КОНФЛИКТА НА ЮГО-ВОСТОКЕ УКРАИНЫ}

\section{Наталия Антонюк, Маркиян Мальский}

Львовский национальный университет имени Ивана Франко, ул. Университетская,1, г. Львов, Украина, 79000, тел. 032-239-46-56 e-mail:nantonyk@yahoo.com; malskyy@ispc.org.ua

Проанализированы особенности российско-украинского конфликта («гибридной войны») и выяснено его значение для европейской безопасности. Охарактеризировано понятие «гибридной войны», ее признаки, методы, структурные елементы. Освещено основные методы информационной агрессии России против Украины, положительные и негативные аспекты дипломатических договоренностей (Минск-1, Минск-2) относительно урегулирования российскоукраинского конфликта на международном уровне. Проанализирована роль международных организаций по урегулированию российско-украинского конфликта.

Ключевые слова: российско-украинский конфликт; гибридная война; информационная война; європейская безопаасность; революция Достоинства; психологическая война; геополитические интересы. 